\title{
Role of Some Phenylthiourea Derivatives as Corrosion Inhibitors for Carbon Steel in $\mathrm{HCl}$ Solution
}

\author{
Abd El-Aziz El-Sayed Fouda* and Ahmed Hussein \\ Department of Chemistry, Faculty of Science, El-Mansoura University, El-Mansoura-35516, Egypt. \\ ${ }^{*}$ E-mail: asfouda@mans.edu.eg \\ (Received October 7, 2011; Accepted January 21, 2012)
}

\begin{abstract}
Five derivatives of phenylthiourea namely: 1-(4-methoxyphenyl)-3-phenylthiourea (1), 1-(4-methylphenyl)-3phenylthiourea (2), 1-(4-bromophenyl)-3-phenylthiourea (3), 1-(4-chlorophenyl)-3-phenylthiourea (4) and 1-phenylthiourea (5) have been evaluated as new inhibitors for the corrosion of carbon steel in $2 \mathrm{M} \mathrm{HCl}$ solution using potentiodynamic polarization and electrochemical impedance spectroscopy (EIS) techniques. Potentiodynamic polarization measurements showed that these derivatives are mixed-type inhibitors. The inhibition efficiency was found to increase with inhibitor concentration and decreases with rise in temperature. The thermodynamic parameters of adsorption and activation were determined and discussed. Nyquist plots showed depressed semicircles with their centre below real axis. The adsorption process of studied derivatives on carbon steel surface obeys Temkin adsorption isotherm. The synergistic effect of these derivatives and some anions is discussed from the viewpoint of adsorption models. The electrochemical results are in good agreement with the calculated quantum chemical HOMO and LUMO energies of the tested molecules.
\end{abstract}

Key words: Corrosion inhibition, Carbon steel, $\mathrm{HCl}$, Phenylthiourea derivatives

\section{INTRODUCTION}

Metallic corrosion is attracting the attention of researchers. Researchers all over the world are searching for some methods to avoid corrosion damage. Using inhibitors is an effective method to reduce corrosion rate. ${ }^{1}$ An acid wash process is widely used in many industries in order to cleaning and descaling of steel substrates and in petrochemical processes. ${ }^{2,3}$ Hydrochloric acid is generally used in the pickling processes of metals and alloys. Because of the general aggressively of acid solutions, inhibitors are commonly used to reduce the corrosive attack on metallic materials as well as acid consumption. Organic compounds are effective inhibitors of aqueous corrosion of many metals and alloys. The influence of organic compounds containing nitrogen, oxygen and sulphur atoms on the corrosion of the steel in acidic solutions has been investigated by several authors. ${ }^{4-13}$ Such compounds can adsorb on the surface of the metal, blocking the active centers on the surface and thus reduces the corrosion rate. In literature, some heterocyclic compounds, ${ }^{14-17}$ Schiff bases ${ }^{18-20}$ and thiadiazoles ${ }^{21-23}$ have been reported as effective corrosion inhibitors for carbon steel in acidic media. The inhibition performance of organic inhibitors is due to physisorption and/or chemisorption on the surface of the metals. ${ }^{24,25}$ To characterize the adsorbed layer and the interaction between adsorbed species, adsorption isotherms are used.

Different methods including potentiodynamic polarization ${ }^{26}$ and electrochemical impedance ${ }^{27}$ techniques have been used to determine surface coverage $(\theta)$, inhibition efficiency (\% IE) and the adsorption isotherm of inhibitor molecules in the corrosive media.

\section{EXPERIMENTAL}

\section{Synthesis of Inhibitors: Phenylthiourea}

Phenylthiourea derivatives (1-5), were synthesized in the laboratory ${ }^{28}$ by reacting equimolecular mixture of the respective phenol and acetimidamide in $100 \mathrm{~mL}$ boiling ethanol. The mixture was refluxed on water bath for 2-6 $\mathrm{h}$ and the solution was evaporated to about its half volume, left to cool where crystals were separated out. These were filtered off, recrystallized from ethanol and finally dried in vacuum desiccators over anhydrous $\mathrm{CaCl}_{2}$. The structure of the compounds were confirmed by elemental analysis and IR and nuclear magnetic resonance (NMR) spectroscopy. The IUPAC name and structure of the five synthesized phenylthiourea derivatives are shown below: 


\begin{tabular}{|c|c|c|c|}
\hline Comp. & Structure & Name & $\begin{array}{c}\text { Formula \& } \\
\text { Molecular Weight }\end{array}$ \\
\hline 1 & & $\begin{array}{l}\text { 1-(4-methoxyphenyl)- } \\
\text { 3-phenylthiourea }\end{array}$ & $\begin{array}{c}\mathrm{C}_{14} \mathrm{H}_{14} \mathrm{~N}_{2} \mathrm{OS} \\
258.34\end{array}$ \\
\hline 2 & & $\begin{array}{l}\text { 1-(4-methylphenyl)-3- } \\
\text { phenylthiourea }\end{array}$ & $\begin{array}{c}\mathrm{C}_{14} \mathrm{H}_{14} \mathrm{~N}_{2} \mathrm{~S} \\
242.34\end{array}$ \\
\hline 3 & & $\begin{array}{l}\text { 1-(4-bromophenyl)-3- } \\
\text { phenylthiourea }\end{array}$ & $\begin{array}{c}\mathrm{C}_{14} \mathrm{H}_{11} \mathrm{BrN}_{2} \mathrm{O} \\
303.15\end{array}$ \\
\hline 4 & & $\begin{array}{l}\text { 1-(4-chlorophenyl)-3- } \\
\text { phenylthiourea }\end{array}$ & $\begin{array}{c}\mathrm{C}_{13} \mathrm{H}_{11} \mathrm{ClN}_{2} \mathrm{~S} \\
262.76\end{array}$ \\
\hline 5 & & 1-phenylthiourea & $\begin{array}{c}\mathrm{C}_{7} \mathrm{H}_{8} \mathrm{~N}_{2} \mathrm{~S} \\
152.22\end{array}$ \\
\hline
\end{tabular}

All the chemicals chosen for our study were of analytical grade and double distilled water was used throughout the experiment. Further, the inhibitor solutions were prepared in ethanol to ensure the solubility. The corrosion tests were performed on carbon steel specimens with a composition (weight \%) C: 0.200, Mn: 0.350, P: 0.024, Si: 0.003 and Fe balance. For electrochemical measurements, the exposed surface area of carbon steel specimens was $1.0 \mathrm{~cm}^{2}$. The surface pre-treatment was carried out by polishing with 600, 800 and 1200 grit emery paper, followed by washing with double distilled water and finally degreased with acetone and dried at room temperature. $2 \mathrm{M} \mathrm{HCl}$ solutions were prepared from an analytical reagent grade of $37 \% \mathrm{HCl}$ and double distilled water and were used as corrosive media in this study. The experiments were performed at $30 \pm 1^{\circ} \mathrm{C}$.

\section{Potentiodynamic Polarization}

Cathodic and anodic polarization curves were recorded in the potential region -800 to $+800 \mathrm{mV}$ (SCE) for different concentrations of investigated phenylthiourea derivatives at a sweep rate $2 \mathrm{mVs}^{-1}$ using Gamry Potentiostat/ Galvanostat/ZRA (Model PCI4/300). Polarization curves in the vicinity of OCP were analyzed to determine the corrosion parameters using Gamry framework/analysis DC105 corrosion software. The corrosion inhibition efficiency (\% IE) was evaluated from the measured $i_{\text {corr }}$ values using the following equation:

$$
\% \text { IE }=\left[1-\left(\mathrm{i}_{\text {corr }} / \mathrm{i}_{\text {corr }}\right)\right] \times 100
$$

where: $i_{\text {corr }}$ and $i_{\text {corr }}$ are the corrosion current densities in the presence and absence of the inhibitor, respectively.

Prior to the electrochemical measurements, a stabilization period of $30 \mathrm{~min}$ was allowed to attain a steady state and the open circuit potential (OCP) was noted. The linear Tafel segments of anodic and cathodic curves were extrapolated to corrosion potential to obtain corrosion current densities ( $\left.i_{\text {corr }}\right)$.

\section{Electrochemical Impedance Spectroscopy (EIS)}

EIS experiments were conducted over a frequency range of $100 \mathrm{kHz}$ to $1 \mathrm{~Hz}$, with a signal amplitude perturbation of $10 \mathrm{mV}$. All impedance data were fitted to an appropriate equivalent circuit using Potentiostat/Galvanostat/ ZRA analyzer (Gamry PC4 300) provided with a personal computer with EIS300 software and Echem Analyst 5.21 for fitting the data and calculations. Nyquist plots were obtained from the results of these experiments. Values of the charge transfer resistance $\left(R_{\mathrm{ct}}\right)$ were obtained from these plots by determining the difference in the values of impedance at low and high frequencies, as suggested by Abdel Rehim et al. ${ }^{29}$ Values of the double layer capacitance $\left(C_{\mathrm{dl}}\right)$ were calculated from the frequency at which the impedance imaginary component $\left(-Z^{\prime \prime}\right)$ was maximum, using the following equation:

$$
C_{d l}=1 /\left(2 \pi \mathrm{f}_{\max } \mathrm{R}_{\mathrm{ct}}\right)
$$

$\%$ IE was calculated using the following equation:

$$
\% \mathrm{IE}=\left(1-\left[\mathrm{R}_{\mathrm{ct}}^{\mathrm{o}} / \mathrm{R}_{\mathrm{ct}}\right]\right) \times 100
$$

where $\mathrm{R}_{\text {ct }}^{\mathrm{a}}$ and $\mathrm{R}_{\mathrm{ct}}$ are the charge transfer resistance in the absence and presence of inhibitor, respectively.

\section{Quantum Study}

Molecular orbital calculations (MOC) are based on the semi-empirical self-consistent methods (SCF). A full optimization of all geometrical variables (bond lengths, bond angles and dihedral angles) without any symmetry constraint was performed at the restricted Hartree-Fock level (RHF). ${ }^{30}$ We used MNDO semi-empirical SCF-MO methods in the MATERIALS STUDIO ${ }^{31,32} \mathrm{DMol}^{3}$ version 4.3, implemented on an Intel Pentium IV, 3.6 GHz computer.

\section{RESULTS AND DISCUSSION}

\section{Polarization Measurements}

The polarization curves for carbon steel in $2 \mathrm{M} \mathrm{HCl}$ in the absence and presence of compound (1) at $30^{\circ} \mathrm{C}$ at dif- 


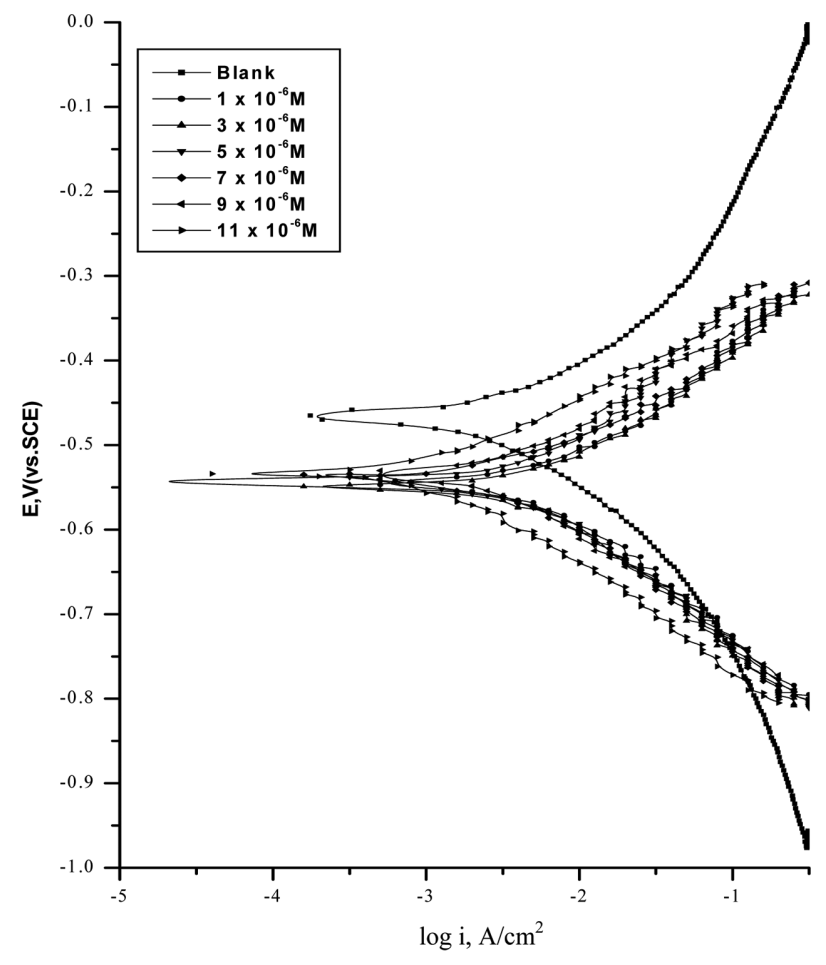

Fig. 1. Polarization curves for carbon steel in $2 \mathrm{M} \mathrm{HCl}$ containing different concentrations of inhibitor (1) at $30^{\circ} \mathrm{C}$.

ferent concentrations are presented in Fig. 1. Similar curves were obtained for other compounds (not shown). All phenylthiourea derivatives show relatively similar behavior in polarization testing. Fig. 1 shows that inhibitor (1) do not change the profile of the anodic and cathodic curves, indicating that it blocks the reaction sites of carbon steel without affecting the anodic and cathodic mechanisms. ${ }^{33}$ The obtained potentiodynamic polarization parameters including corrosion current density ( $\mathrm{i}_{\text {corr }}$ ), corrosion potential $\left(\mathrm{E}_{\mathrm{corr}}\right)$, cathodic $\left(\mathrm{b}_{\mathrm{c}}\right)$ and anodic $\left(\mathrm{b}_{\mathrm{a}}\right)$ Tafel slopes, polar- ization resistance $\left(R_{p}\right)$, degree of surface coverage $(\theta)$ and the inhibition efficiency (IE) are listed in Table 1.

The results of Table 1 show that the inhibition efficiency of these inhibitors increases and corrosion current density decreases with increasing inhibitor concentration. The corrosion inhibition efficiency of phenylthiourea derivatives decreases in the order: $1>2>3>4>5$.

With the inhibitors, both anodic and cathodic current densities are reduced, the change of Tafel slopes upon addition of inhibitors, which means that the inhibitor molecules are adsorbed on both anodic and cathodic sites, and the slight change of $E_{\text {corr }}$, all these suggested that these compounds behave as mixed type inhibitors.

The higher values of Tafel slope can be attributed to surface kinetic process rather the diffusion-controlled process. ${ }^{34}$ The parallel of cathodic and anodic Tafel lines obtained from the electrochemical measurements indicates that the addition of these derivatives did not modify the mechanism of this process. ${ }^{30}$ The order of decreased inhibition efficiency obtained from this method for investigated additives is: $1>2>3>4>5$.

\section{Synergistic Effect}

To further clarify the modes of inhibitor adsorption, experiments were conducted in the presence of $\mathrm{KSCN}, \mathrm{KI}$ and $\mathrm{KBr}\left(\mathrm{X}^{-}\right)$ions, which are strongly adsorbed on the surface of carbon steel in acidic solution and facilitate adsorption of organic cation-type inhibitors by acting as intermediate bridges between the positive end of the organic cation and the positively charged metal surface. Specific adsorption of these anions on the metal surface leads to a recharging of the electrical double layer. The inhibitor is then drawn into the double layer by electrostatic interaction with the adsorbed $\mathrm{X}^{-}$ions, forming ion pairs on the metal surface

Table 1. Kinetic parameters of carbon steel in $2 \mathrm{M} \mathrm{HCl}$ containing various concentrations of inhibitor (1) and $11 \times 10^{-6} \mathrm{M}$ inhibitors (2-5) at $30^{\circ} \mathrm{C}$

\begin{tabular}{|c|c|c|c|c|c|c|c|c|c|}
\hline Comp. & $\begin{array}{l}\text { Conc., } \times 10^{6} \\
(\mathrm{M})\end{array}$ & $\begin{array}{c}-\mathrm{E}_{\text {corr }} \\
(\mathrm{mV} \text { vs. SCE) }\end{array}$ & $\begin{array}{c}\mathrm{i}_{\text {corr }} \\
\left(\mathrm{mA} \mathrm{cm}^{-2}\right)\end{array}$ & $\theta$ & $\% \mathrm{IE}_{\text {icorr }}$ & $\begin{array}{c}\beta_{\mathrm{c}} \\
\left(\mathrm{mVdec}^{-1}\right)\end{array}$ & $\begin{array}{c}\beta_{\mathrm{a}} \\
\left(\mathrm{mVdec}^{-1}\right)\end{array}$ & $\begin{array}{c}\mathrm{R}_{\mathrm{p}} \\
\left(\Omega \mathrm{cm}^{2}\right)\end{array}$ & $\% \mathrm{IE}_{\mathrm{Rp}}$ \\
\hline Blank & 0.0 & 468 & 9.207 & - & - & 306 & 270 & 8.943 & - \\
\hline \multirow{6}{*}{1} & 1 & 555 & 8.416 & 0.082 & 8.2 & 158 & 151 & 7.106 & 8.1 \\
\hline & 3 & 548 & 7.306 & 0.206 & 20.6 & 163 & 133 & 6.902 & 22.8 \\
\hline & 5 & 545 & 5.974 & 0.351 & 35.1 & 149 & 158 & 5.703 & 36.2 \\
\hline & 7 & 537 & 5.401 & 0.413 & 41.3 & 154 & 121 & 5.302 & 40.7 \\
\hline & 9 & 533 & 4.683 & 0.491 & 49.1 & 135 & 119 & 4.603 & 48.5 \\
\hline & 11 & 532 & 1.529 & 0.833 & 83.3 & 131 & 103 & 1.308 & 85.3 \\
\hline 2 & 11 & 522 & 3.149 & 0.658 & 65.8 & 129 & 103 & 1.894 & 78.8 \\
\hline 3 & 11 & 537 & 4.617 & 0.498 & 49.8 & 143 & 107 & 4.287 & 52.0 \\
\hline 4 & 11 & 542 & 4.691 & 0.490 & 49.0 & 150 & 129 & 4.462 & 50.1 \\
\hline 5 & 11 & 527 & 5.036 & 0.453 & 45.3 & 134 & 102 & 4.548 & 49.1 \\
\hline
\end{tabular}


Table 2. Kinetic parameters of carbon steel in $2 \mathrm{M} \mathrm{HCl}$ containing various concentrations of inhibitors and in the presence of $1 \times 10^{-2} \mathrm{M} \mathrm{KI}$ at $30^{\circ} \mathrm{C}$

\begin{tabular}{cccccccccc}
\hline Comp. & $\begin{array}{c}\text { Conc., } \times 10^{6} \\
(\mathrm{M})\end{array}$ & $\begin{array}{c}-\mathrm{E}_{\text {corr }} \\
(\mathrm{mV} \text { vs. SCE })\end{array}$ & $\begin{array}{c}\mathrm{i}_{\text {corr }} \\
(\mathrm{mA} \mathrm{cm})\end{array}$ & $\theta$ & $\% \mathrm{IE}_{\text {icorr }}$ & $\begin{array}{c}\beta_{\mathrm{c}} \\
\left(\mathrm{mVdec}^{-1}\right)\end{array}$ & $\begin{array}{c}\beta_{\mathrm{a}} \\
\left(\mathrm{mVdec}^{-1}\right)\end{array}$ & $\begin{array}{c}\mathrm{R}_{\mathrm{p}} \\
\left(\Omega \mathrm{cm}^{2}\right)\end{array}$ & \begin{tabular}{c}
$\% \mathrm{IE}_{\mathrm{Rp}}$ \\
\hline Blank
\end{tabular} \\
\hline .0 & 468 & 9.207 & - & - & 306 & 270 & 8.943 & - \\
\hline & 1 & 544 & 8.302 & 0.098 & 9.8 & 160 & 142 & 7.043 & 21.2 \\
& 3 & 547 & 7.216 & 0.216 & 21.6 & 162 & 140 & 6.779 & 24.1 \\
1 & 5 & 546 & 5.906 & 0.358 & 35.8 & 143 & 159 & 5.199 & 37.3 \\
& 7 & 539 & 5.299 & 0.424 & 42.4 & 150 & 121 & 5.306 & 41.8 \\
& 9 & 536 & 4.399 & 0.522 & 52.2 & 137 & 126 & 4.499 & 49.6 \\
& 11 & 535 & 1.013 & 0.889 & 88.9 & 129 & 108 & 0.861 & 90.3 \\
\hline 2 & 11 & 532 & 1.096 & 0.880 & 88.0 & 131 & 102 & 0.879 & 90.1 \\
\hline 3 & 11 & 538 & 31.102 & 0.880 & 88.0 & 141 & 109 & 0.893 & 90.0 \\
\hline 4 & 11 & 547 & 1.167 & 0.873 & 87.3 & 147 & 113 & 0.901 & 89.9 \\
\hline 5 & 11 & 519 & 1.197 & 0.869 & 86.9 & 137 & 104 & 0.935 & 89.5 \\
\hline
\end{tabular}

which increases the degree of surface coverage

$$
\begin{aligned}
& \mathrm{X}_{\text {sol }}^{-} \rightarrow \mathrm{X}_{\text {ads }}^{-} \\
& \mathrm{X}_{\text {ads }}^{-}+\operatorname{inh}_{\text {sol }}^{+} \rightarrow\left[\mathrm{X}^{-}-\mathrm{inh}^{+}\right]_{\text {ads }}
\end{aligned}
$$

The effect of addition $1 \times 10^{-2} \mathrm{M} \mathrm{KSCN}, \mathrm{KI}$ and $\mathrm{KBr}$ on the corrosion rate of carbon steel in the absence and presence of different concentrations of inhibitors (1-5) in $2 \mathrm{M}$ $\mathrm{HCl}$ solutions was investigated using potentiodynamic polarization method. Results of the kinetic parameters in presence of anions $\left(\mathrm{X}^{-}\right)$are summarized in Table 2. It was observed from these results that these additives improved the $\% I E$ significantly. The interactions of these additives with the inhibitor molecules can be described by introduction of the synergistic parameter $\left(\mathrm{S}_{\theta}\right)$ which is defined as: ${ }^{35}$

$$
\mathrm{S}_{\theta}=1-\theta_{1+2} / 1-\theta^{\prime}{ }_{1+2}
$$

where $\theta_{1+2}=\left(\theta_{1}+\theta_{2}\right)-\left(\theta_{1} \theta_{2}\right), \theta_{1}=$ surface coverage by anion $\left(1 \mathrm{M} \mathrm{HCl}+1 \times 10^{-2} \mathrm{M} \mathrm{X}^{-}\right.$only $), \theta_{2}=$ surface coverage by cation ( $1 \mathrm{M} \mathrm{HCl}+$ Inhibitor only) and $\theta_{1+2}^{\prime}=$ measured surface coverage by both the anion and cation ( $1 \mathrm{M} \mathrm{HCl}+\mathrm{X}^{-}+$inhibitor). $S_{\theta}$ approaches 1 when no interaction between the inhibitor compounds exists, while $S_{\theta}>$ 1 points to a synergistic effect. In the case of $S_{\theta}<1$, the antagonistic interaction prevails. Values of $S_{\theta}$ summarized in Tables 3 are more than unity, suggesting that the phenomenon of synergism exists between the inhibitors and these additives. Larabi et al. ${ }^{36}$ has proposed two kinds of joint adsorption (competitive and cooperative) to explain the synergistic action observed between anion and cation. ${ }^{37}$ For competitive adsorption, the anion and cation are adsorbed at different sites on the electrode surface and for cooperative adsorption, the anion is chemisorbed on the
Table 3. Synergism parameter $\left(S_{\theta}\right)$ for different concentrations of investigated inhibitors for carbon steel dissolution in $2 \mathrm{M} \mathrm{HCl}$ with addition of $1 \times 10^{-2} \mathrm{M} \mathrm{KI}$ at $30^{\circ} \mathrm{C}$

\begin{tabular}{cccccc}
\hline \multirow{2}{*}{ Conc., $(\mathrm{M})$} & \multicolumn{5}{c}{ Synergism parameter $\left(\mathrm{S}_{\theta}\right)$} \\
\cline { 2 - 6 } & 1 & 2 & 3 & 4 & 5 \\
\hline $1 \times 10^{-6}$ & 1.0 & 1.1 & 1.0 & 1.1 & 1.0 \\
$3 \times 10^{-6}$ & 1.2 & 1.1 & 1.1 & 1.1 & 1.1 \\
$5 \times 10^{-6}$ & 1.1 & 1.0 & 1.3 & 1.2 & 1.0 \\
$7 \times 10^{-6}$ & 1.3 & 1.0 & 1.0 & 1.0 & 1.2 \\
$9 \times 10^{-6}$ & 1.2 & 1.0 & 1.1 & 1.0 & 1.0 \\
$11 \times 10^{-6}$ & 1.2 & 1.2 & 1.2 & 1.3 & 1.1 \\
\hline
\end{tabular}

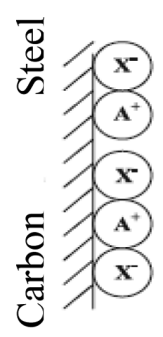

(a)

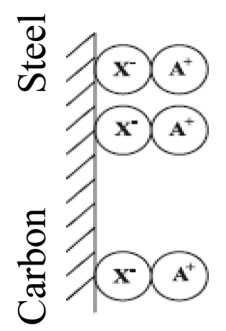

(b)
Fig. 2. Schematic representations of (a) competitive and (b) cooperative adsorption of the anions $\left(\mathrm{X}^{-}\right)$and cations $\left(\mathrm{A}^{+}\right)$on carbon steel surface in acid solutions.

surface and the cation is adsorbed on the layer of the anions. The two types of adsorption are represented schematically in Fig. 2 and can be characterized by a synergistic factor $\left(S_{\theta}\right)$ calculated as above. So, the synergistic inhibitive effect is due to the combination of the inhibitor molecules with $\mathrm{KSCN}, \mathrm{KI}$ and $\mathrm{KBr}$ as explained before.

\section{Adsorption Isotherm}

The nature of corrosion inhibition has been deduced in 
terms of the adsorption characteristics of the inhibitor. Metal surface in aqueous solution is always covered with adsorbed water dipoles. Therefore adsorption of adsorbate on a metal surface is regarded as a substitutional adsorption process between the organic molecule in the aqueous solution (Org $\left.\mathrm{sol}_{\mathrm{si}}\right)$, and water molecules adsorbed on metallic surface $\left(\mathrm{H}_{2} \mathrm{O}_{\mathrm{ads}}\right){ }^{37}$

$$
\mathrm{Org}_{\text {sol }}+\mathrm{x} \mathrm{H}_{2} \mathrm{O}_{\mathrm{ads}} \rightarrow \mathrm{Org}_{\mathrm{ads}}+\mathrm{x} \mathrm{H}_{2} \mathrm{O}_{\text {sol }}
$$

A correlation between surface coverage $(\theta)$ defined by $\% \mathrm{IE} / 100$ and the concentration of inhibitor $\left(\mathrm{C}_{\mathrm{inh}}\right)$ in electrolyte can be represented by Temkin adsorption isotherm,

$\ln \mathrm{K} \mathrm{C}=\mathrm{a} \theta$

where $\mathrm{K}$ is the equilibrium constant of the adsorption reaction and ' $\mathrm{a}$ ' is the lateral interaction term describing the interactions in the adsorption layer and the heterogeneity of the surface (it is a measure for the steepness of the adsorption isotherms). Surface coverage values $(\theta)$ for the inhibitors were obtained from the polarization measurements for various concentrations.

The best fitted straight line is obtained for the plot of $\Theta$ versus $\log \mathrm{C}$. The correlation coefficient $\left(\mathrm{R}^{2}>0.98\right)$ was used to choose the isotherm that best fit experimental data. This suggests that the adsorption of these compounds on metal surface followed the Temkin adsorption isotherm (Fig. 3). From the intercepts of straight lines, $\mathrm{K}$ values were calculated and are given in Table 4 . The most important thermodynamic adsorption parameters are the free energy of adsorption $\left(\Delta G_{a d s}^{o}\right)$, the adsorption constant $(\mathrm{K})$ is related to the standard free energy of adsorption, $\Delta G_{a d s}^{o}$, with the following equation ${ }^{38}$ :

$$
K=1 / 55.5 \exp \left(-\Delta G_{\text {ads }}^{o} / \mathrm{RT}\right)
$$

where 55.5 is the water concentration of solution in $\mathrm{ml} / \mathrm{l}^{39}$ The standard free energy of adsorption $\left(\Delta G_{a d s}^{o}\right)$ values were calculated and given in Table 4 . The negative values of $\Delta G_{a d s}^{o}$ indicate the stability of the adsorbed layer on the steel surface and spontaneity of the adsorption process.

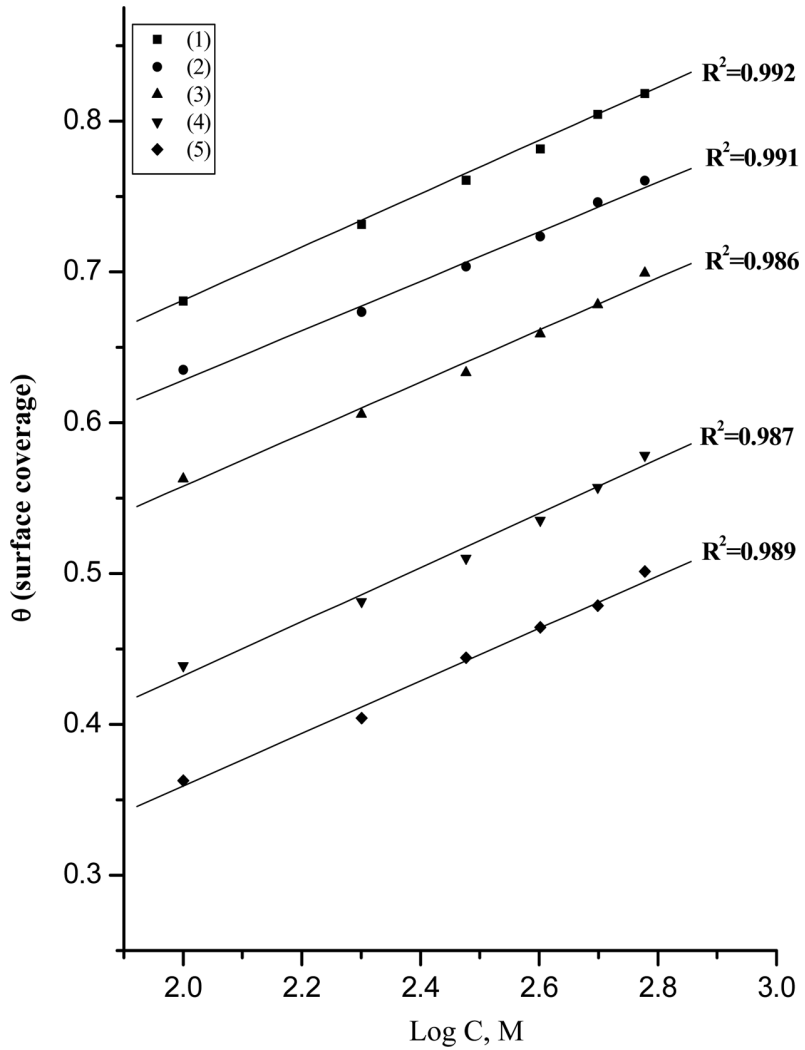

Fig. 3. Temkin adsorption plots for carbon steel surface in $2 \mathrm{M}$ $\mathrm{HCl}$ solution containing different concentrations of investigated inhibitors at $30^{\circ} \mathrm{C}$.

Generally, values of $\Delta G_{a d s}^{o}$ up to $-20 \mathrm{~kJ} \mathrm{~mol}^{-1}$ are consistent with the electrostatic interaction between the charged molecules and the charged metal (physical adsorption) while those more negative than $-40 \mathrm{~kJ} \mathrm{~mol}^{-1}$ involve sharing or transfer of electrons from the inhibitor molecules to the metal surface to form a coordinate type of bond (chemisorptions). ${ }^{40}$ The values of $\Delta G_{\text {ads }}^{o}$ obtained were approximately equal to $-59.21 \mathrm{~kJ} \mathrm{~mol}^{-1}$, indicating that the adsorption mechanism of the phenylthiourea derivatives on carbon steel in $2 \mathrm{M} \mathrm{HCl}$ solution involves both electrostatic adsorption and chemisorptions. The thermodynamic parameters point toward both physisorption (major

Table 4. Inhibitor equilibrium constant $(\mathrm{K})$, free energy of adsorption $\left(\Delta G_{a d s}^{o}\right)$, number of active sites (1/y) and the interaction parameter

\begin{tabular}{|c|c|c|c|c|c|c|}
\hline \multirow{2}{*}{ Inhibitors } & \multicolumn{3}{|c|}{ Kinetic model } & \multicolumn{3}{|c|}{ Temkin } \\
\hline & $1 / y$ & $\mathrm{~K} \times 10^{-2}\left(\mathrm{M}^{-1}\right)$ & $-\Delta G_{a d s}^{o},\left(\mathrm{~kJ} \mathrm{~mol}^{-1}\right)$ & $\mathrm{a}$ & $\mathrm{K} \times 10^{-2}\left(\mathrm{M}^{-1}\right)$ & $-\Delta G_{a d s}^{o},\left(\mathrm{~kJ} \mathrm{~mol}^{-1}\right)$ \\
\hline 1 & 3.04 & 0.899 & 59.2 & 13.99 & 0.710 & 62.0 \\
\hline 2 & 3.21 & 0.858 & 57.8 & 13.03 & 0.663 & 61.9 \\
\hline 3 & 3.07 & 0.676 & 53.4 & 12.96 & 0.162 & 51.8 \\
\hline 4 & 2.03 & 0.601 & 51.3 & 12.67 & 0.030 & 38.0 \\
\hline 5 & 2.12 & 0.443 & 47.2 & 12.34 & 0.020 & 32.1 \\
\hline
\end{tabular}
(a) for investigated inhibitors at $30^{\circ} \mathrm{C}$. 


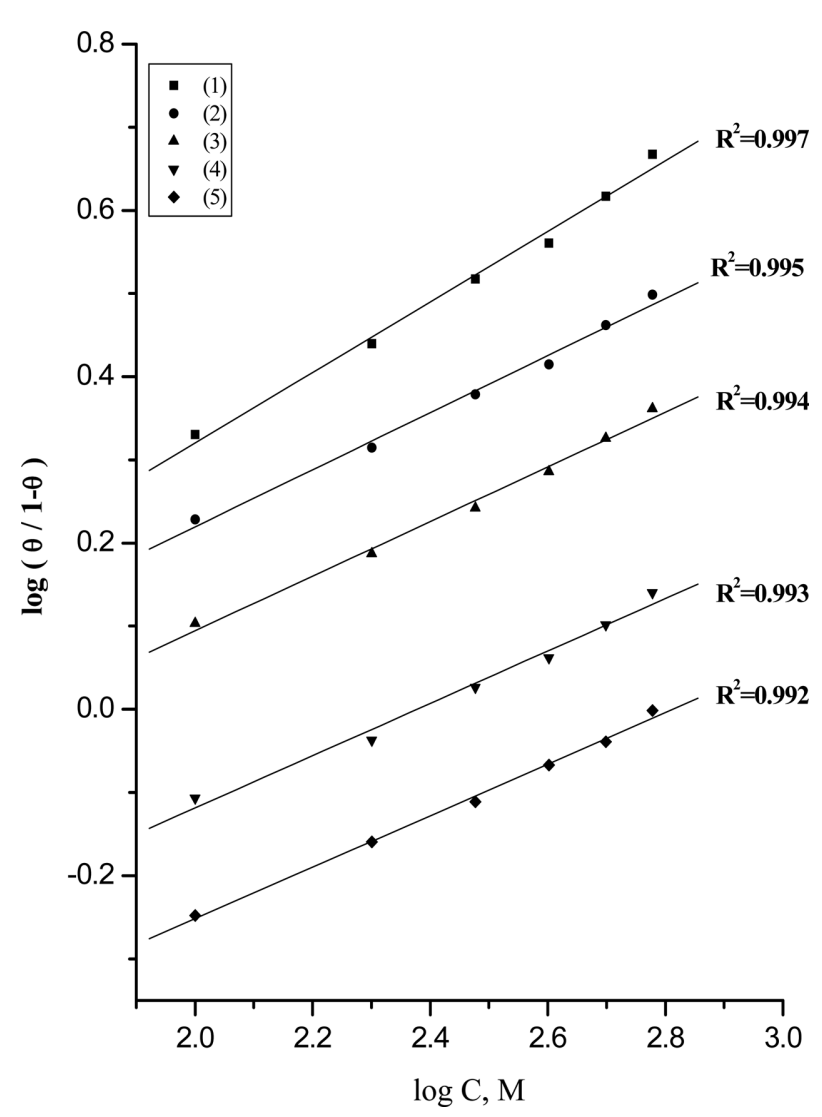

Fig. 4. Curve fitting of corrosion data for carbon steel in $2 \mathrm{M}$ $\mathrm{HCl}$ containing different concentrations of investigated inhibitors corresponding to kinetic model.

contributor) and chemisorptions (minor contributor) of the inhibitors onto the metal surface. The $\mathrm{K}_{\mathrm{ads}}$ values follow the same trend. Large values of $\mathrm{K}_{\mathrm{ads}}$ imply better efficient adsorption and hence better inhibition efficiency. ${ }^{41}$

On the other hand, it was found that Kinetic-thermodynamic model of El-Awady et al. ${ }^{42}$ which has the formula:

$$
\log (\Theta / 1-\Theta)=\log \mathrm{K}^{\prime}-\mathrm{y} \log \mathrm{C}
$$

Can be applied and verify the present adsorption data (Fig. 4). The equilibrium constant of adsorption $K=K^{(1 / y)}$, where $1 / \mathrm{y}$ is the number of the surface active sites occupied by one phenylthiourea molecule and $\mathrm{C}$ is the bulk concentration of the inhibitor.

\section{Effect of Temperature}

Corrosion reactions are usually regarded as Arrhenius processes and the rate $(k)$ can be expressed by the relation:

$$
\text { Rate }(\mathrm{k})=\mathrm{A} \exp \left(-E_{a}^{*} / \mathrm{RT}\right)
$$

where $E_{a}^{*}$ is the activation energy of the corrosion process $\mathrm{R}$ is the universal gas constant, $\mathrm{T}$ is the absolute temper-

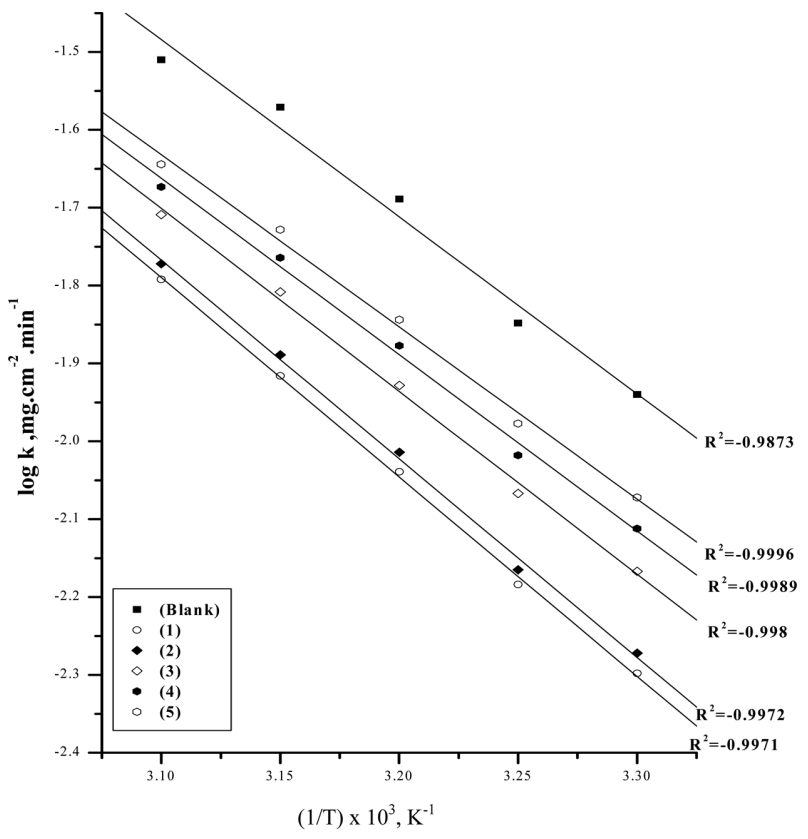

Fig. 5. Arrhenius plots for carbon steel corrosion in $2 \mathrm{M} \mathrm{HCl}$ containing $9 \times 10^{-6} \mathrm{M}$ of inhibitors.

ature and $\mathrm{A}$ is a Arrhenius pre-exponential constant depends on the metal type and electrolyte. Arrhenius plots of log k vs. $1 / \mathrm{T}$ for carbon steel in $2 \mathrm{M} \mathrm{HCl}$ in the absence and presence of $9 \times 10^{-6} \mathrm{M}$ of inhibitors are shown graphically in Fig. 5. The variation of $\log \mathrm{k}$ vs. $1 / \mathrm{T}$ is a linear one and the values of $E_{a}$ obtained are summarized in Table 5 . These results suggested that the inhibitors are similar in their mechanism of action. The increase in $E_{a}^{*}$ with the addition of inhibitors, indicates that the energy barrier for the corrosion reaction increases. It is also indicated that the whole process is controlled by surface reaction, since the activation energy of the corrosion process is over $20 \mathrm{~kJ}$ $\mathrm{mol}^{-1} .^{43}$ Enthalpy and entropy of activation $\left(\Delta \mathrm{H}^{*}, \Delta \mathrm{S}^{*}\right)$ are calculated from transition state theory using the following equation: $^{44}$

$$
\text { Rate }(\mathrm{k})=(\mathrm{RT} / \mathrm{Nh}) \exp \left(\Delta \mathrm{S}^{*} / \mathrm{R}\right) \exp \left(-\Delta \mathrm{H}^{*} / \mathrm{RT}\right)
$$

where $h$ is Planck's constant, $N$ is Avogadro's number. A plot of $\log \mathrm{k} / \mathrm{T}$ vs $1 / \mathrm{T}$ also gaves straight lines as shown in Fig. 6 for carbon steel in $2 \mathrm{M} \mathrm{HCl}$ in the absence and presence of $9 \times 0^{-6} \mathrm{M}$ concentration of inhibitors. The slopes of these lines equal to $\Delta H^{*} / 2.303 \mathrm{R}$ and their intercepts equal to $\left[\log \mathrm{RT} / \mathrm{Nh}+\left(\Delta \mathrm{S}^{*} / 2.303 \mathrm{R}\right)\right]$ from which the values of $\Delta \mathrm{H}^{*}$ and $\Delta \mathrm{S}^{*}$ can be calculated and are tabulated in Table 5. From these results, it is clear that the presence of these compounds increases the activation energy values and consequently decreased the corrosion rate of the carbon 
Table 5. Activation parameters for carbon steel corrosion in $2 \mathrm{M}$ $\mathrm{HCl}$ acid solution containing $9 \times 10^{-6} \mathrm{M}$ of inhibitors

\begin{tabular}{cccc}
\hline \multirow{2}{*}{ Inhibitor } & \multicolumn{3}{c}{ Activation parameters } \\
\cline { 2 - 4 } & $\mathrm{E}_{\mathrm{a}}^{*},\left(\mathrm{~kJ} \mathrm{~mol}^{-1}\right)$ & $\Delta \mathrm{H}^{*},\left(\mathrm{~kJ} \mathrm{~mol}^{-1}\right)$ & $-\Delta \mathrm{S}^{*},\left(\mathrm{~J} \mathrm{~mol}^{-1} \mathrm{~K}^{-1}\right)$ \\
\hline Blank & 42.4 & 40.01 & 153.6 \\
1 & 48.1 & 46.1 & 135.4 \\
2 & 47.9 & 44.2 & 136.1 \\
3 & 43.8 & 42.3 & 145.8 \\
4 & 42.2 & 41.0 & 150.3 \\
5 & 41.2 & 40.0 & 152.8 \\
\hline
\end{tabular}

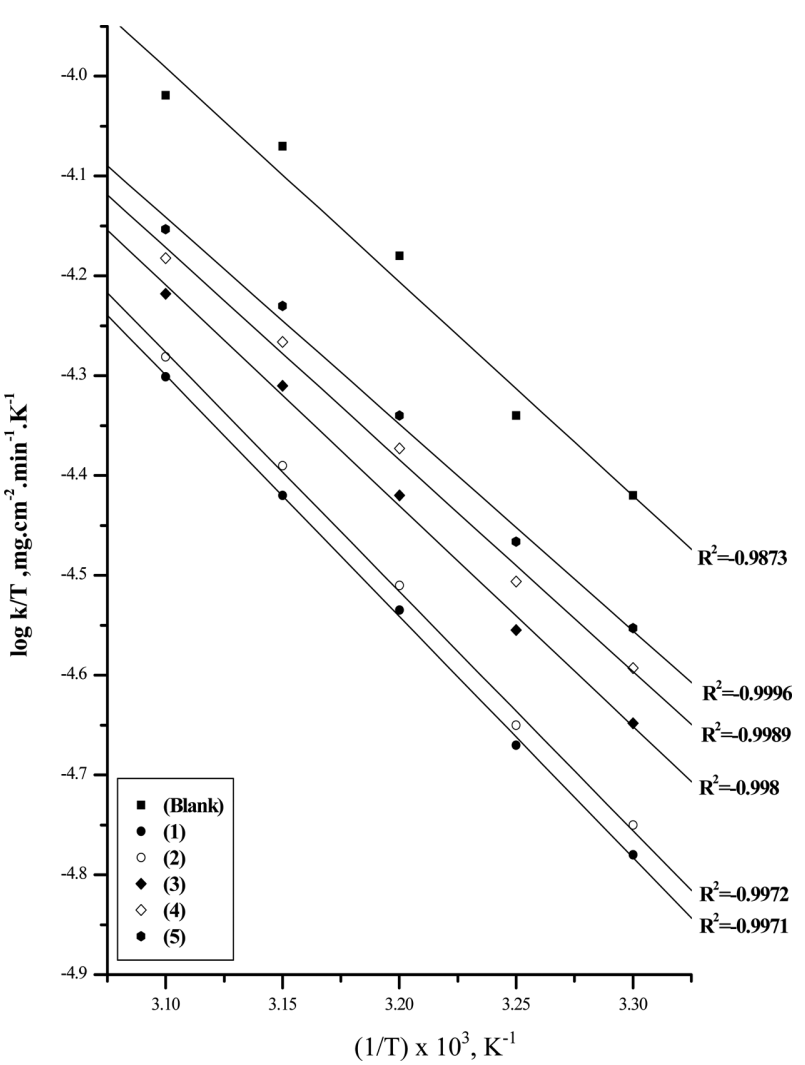

Fig. 6. Transition state plots for carbon steel corrosion in $2 \mathrm{M}$ $\mathrm{HCl}$ containing $9 \times 10^{-6} \mathrm{M}$ of inhibitors.

steel. $\Delta \mathrm{H}^{*}$ values reflect the strong adsorption of these compounds on carbon steel surface. $\Delta \mathrm{S}^{*}$ values in the presence of these investigated compounds are larger and negative; this indicates that the activated complex in the rate determining step represents an association rather than dissociation step, meaning that a decreases in disordering takes place on going from reactants to the activated complex and the activated molecules were in higher order state than that at the initial state. ${ }^{45,46}$

\section{Electrochemical Impedance Spectroscopy}

The corrosion behavior of mild steel in $1 \mathrm{M} \mathrm{HCl}$ solu-

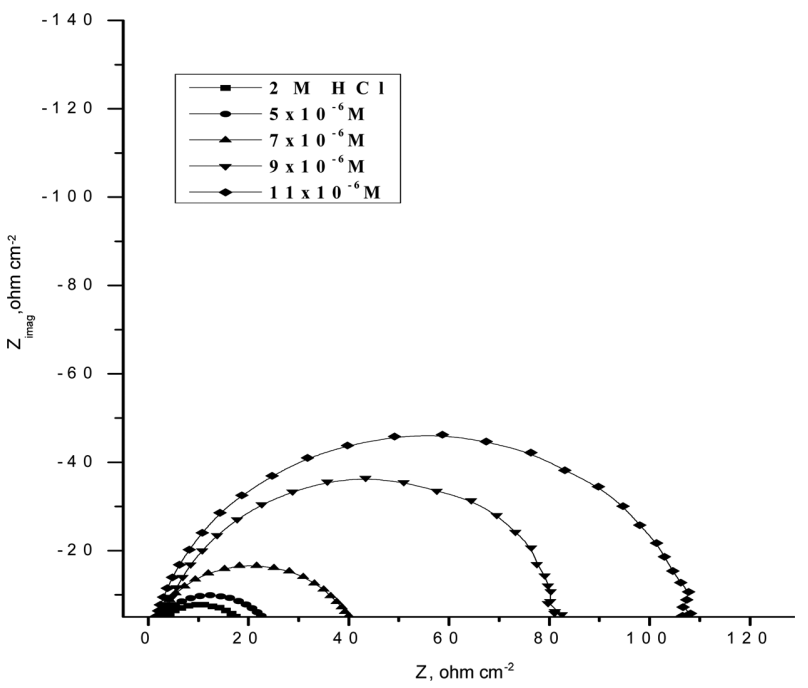

Fig. 7. Nyquist plots of carbon steel in $2 \mathrm{M} \mathrm{HCl}$ containing various concentrations of inhibitor (1).

tion in the presence of various concentrations of compound (1) was investigated by EIS at $30^{\circ} \mathrm{C}$ after $30 \mathrm{~min}$ of immersion. Fig. 7 shows the results of EIS experiments in the Nyquist representation. After analyzing the shape of the Nyquist plots, it is concluded that the curves approximated by a single capacitive semi-circles, showing that the corrosion process was mainly charge transfer controlled. ${ }^{47}$ The fact that impedance diagrams have an approximately semicircular appearance shows that the corrosion of carbon steel is controlled by a charge transfer process. Small distortion was observed in some diagrams, this distortion has been attributed to frequency dispersion. ${ }^{48}$ The general shape of the curves is very similar for all samples, indicating that almost no change in the corrosion mechanism occurred due to the inhibitor addition. ${ }^{49}$ The diameter of Nyquist plots increases on increasing the inhibitor concentration. These results suggested that the inhibition efficiency increases by increasing inhibitor concentrations. The Nyquist plots are analyzed in terms of the equivalent circuit composed with classic parallel capacitor and resistor (shown in Fig. 8). ${ }^{50}$ EIS parameters and \% IE were calculated and tabulated in Table 6 for inhibitor 1. It was observed from the obtained EIS data that the charge trans-

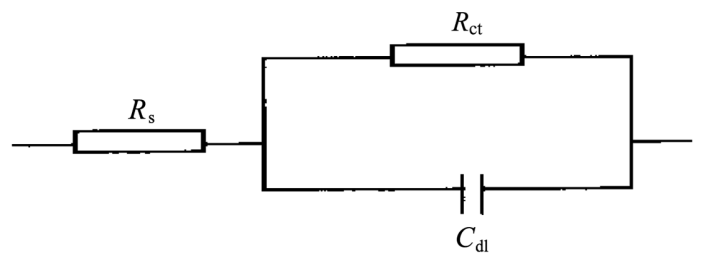

Fig. 8. Electrical equivalent circuit used to fit the impedance data. 
Table 6. Electrochemical kinetic parameters obtained from EIS technique for the corrosion of carbon steel in $2 \mathrm{M} \mathrm{HCl}$ at different concentrations of inhibitor $(1)$ at $30^{\circ} \mathrm{C}$

\begin{tabular}{ccccc}
\hline Conc., $\mathrm{M}$ & $\mathrm{C}_{\mathrm{dl}},\left(\mu \mathrm{F} \mathrm{cm}^{-2}\right)$ & $\mathrm{R}_{\mathrm{ct}},\left(\Omega \mathrm{cm}^{2}\right)$ & $\Theta$ & $\% \mathrm{IE}$ \\
\hline Blank & 98.02 & 19.03 & - & - \\
$5 \times 10^{-6}$ & 96.36 & 27.43 & 0.296 & 29.6 \\
$7 \times 10^{-6}$ & 94.74 & 44.77 & 0.569 & 56.9 \\
$9 \times 10^{-6}$ & 90.03 & 85.03 & 0.773 & 77.3 \\
$11 \times 10^{-6}$ & 86.90 & 122.06 & 0.842 & 84.2 \\
\hline
\end{tabular}

fer resistance $\left(R_{\mathrm{ct}}\right)$ increases and double layer capacitance $\left(C_{\mathrm{dl}}\right)$ decreases with the increasing of inhibitor concentrations. The increase in $R_{\mathrm{ct}}$ values, and consequently of inhibition efficiency, may be due to the gradual replacement of water molecules by the adsorption of the inhibitor molecules on the metal surface to form an adherent film on the metal surface, this suggests that the coverage of the metal surface by the film decreases the double layer thickness. Also, the decrease of $C_{\mathrm{dl}}$ means that the adsorption of inhibitor takes place on carbon steel surface in acidic solution. The results indicate good agreement between the values of corrosion efficiency as obtained from the impedance technique and polarization measurements. It was concluded that the corrosion rate depends on the chemical nature of the electrolyte rather than the applied technique. ${ }^{51}$

\section{Quantum Chemical Study}

It had been reported that the energy of highest occupied molecular orbital (Еномо) often associated with the electron donating ability of the molecules. High values of

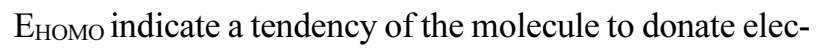
trons to act with acceptor molecules with low-energy, empty molecular orbital. Similarly, the energy of lowest unoccupied molecular orbital ( $\mathrm{E}_{\mathrm{LUMO}}$ ) represents the ability of the molecule to accept electrons. The lower value of $\mathrm{E}_{\text {LUMO }}$ suggests the molecule accepts electrons more probable. ${ }^{52}$ The calculated quantum chemical indices, $\mathrm{E}_{\text {номо, }}$ $\mathrm{E}_{\text {LUMO }}$, energy gap $(\Delta \mathrm{E})$ and dipole moment $(\mu)$, of investigated compounds are calculated and are shown in Table 7. Inhibition efficiency increases with increasing values of

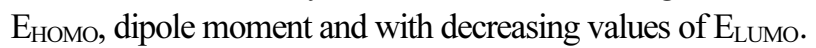
The results seem to indicate, that charge transfer from the inhibitor takes place during the adsorption to the metal surface. Increasing values of $\mathrm{E}_{\text {Номо }}$ and may facilitate adsorption (and therefore inhibition) by influencing the transport process through the adsorbed layer. ${ }^{53}$ Similar relations were found between the inhibition efficiency and the energy gap $\Delta \mathrm{E} .{ }^{51}$ Lower values of the energy gap will render good inhibition, because the energy to remove an
Table 7. The calculated quantum chemical parameters for investigated inhibitors

\begin{tabular}{cccccc}
\hline \multirow{2}{*}{ Parameter } & \multicolumn{5}{c}{ Inhibitors } \\
\cline { 2 - 6 } & 1 & 2 & 3 & 4 & 5 \\
\hline$-\mathrm{E}_{\text {Homo }}(\mathrm{ev})$ & 8.002 & 8.012 & 8.213 & 8.934 & 10.233 \\
$-\mathrm{E}_{\text {Lumo }}(\mathrm{ev})$ & 1.314 & 1.322 & 1.422 & 1.448 & 2.001 \\
$\Delta \mathrm{E},\left(\mathrm{eV} \mathrm{mol}^{-1}\right)$ & 6.688 & 6.690 & 6.791 & 7.486 & 8.232 \\
$\mu,($ Debye $)$ & 3.025 & 4.223 & 6.043 & 9.025 & 11.014 \\
Molecular weight & 254.28 & 238.28 & 303.15 & 258.7 & 148.16 \\
\hline
\end{tabular}

electron from the last occupied orbital will be low.

The dipole moment is another way to obtain data on electronic distribution in a molecule and is one of the properties more used traditionally to discuss and rationalize the structure and reactivity of many chemical systems. ${ }^{54}$ The values of $\mathrm{E}_{\text {Номо }}$ show the relation $1>2>3>4>5$ for this property. In addition, the values of the energy gap $\Delta \mathrm{E}$ show the relation $5>4>3>2>1$ for this property. The results of Table 7 show that the values of $\mu$ (dipole moment) decreases in the following order: $5>4>3>2>1$. Some authors showed that an increase of the dipole moment leads to decrease of inhibition and vice versa, suggesting that lower values of dipole moment will favor accumulation of inhibitor in the surface layer. ${ }^{55}$ In contrast, the increase in the dipole moment can lead to increase of inhibition and vice versa, ${ }^{56,57}$ which could be related to the dipole-dipole interaction of molecules and metal surface. The higher the value of $\mu$ obtained is coherent with the second explanation indicating stronger dipole-dipole interactions of inhibitors molecules and metallic surface.

\section{Mechanism of Corrosion Inhibition}

From the previous results, it was concluded that the investigated inhibitors (1-5) inhibit the corrosion of carbon steel in $2 \mathrm{M} \mathrm{HCl}$ by adsorption at the metal/solution interface. Compound (1) exhibits excellent inhibition power due to: (i) the presence of $\mathrm{p}-\mathrm{OCH}_{3}$ group which is an electron donating group with negative Hammett constant $(\sigma=$ -0.27 ), which enhance the delocalized $\pi$-electrons on the active centers of the compound and may serve as adsorption centre, (ii) its larger molecular size that may facilitate better surface coverage, and (iii) its adsorption through three active centers. Compound (2) comes after compound (1) in inhibition efficiency due to: (i) its lower molecular size than compound (1) (ii) the presence of two active adsorption centers only and (iii) the presence of $\mathrm{p}-\mathrm{CH}_{3}(\sigma$ $=-0.17$ ) with low Hammett constant than $\mathrm{p}-\mathrm{OCH}_{3}$ which enhances the delocalized $\pi$-electrons on the active centers of the compound. Compounds (3) and (4) come after com- 
pound (2) in percentage inhibition efficiencies. This is due to the presence of $\mathrm{p}-\mathrm{Br}$ and $\mathrm{p}-\mathrm{Cl}$ groups which are electron withdrawing groups with positive Hammett constants $\left(\sigma_{\mathrm{Br}}=+0.232, \sigma_{\mathrm{Cl}}=+0.227\right)$ and their order of inhibition depends on the magnitude of their withdrawing character and their molecular size. Compound (5) comes after compound (4) in inhibition efficiency inspite of it has three active centers, because it has lower molecular size than compound (4) and has no substituents in the p-position which contributes no charge density to the molecule.

\section{CONCLUSION}

1) Phenylthiourea derivatives are good inhibitors for corrosion of carbon steel in $2 \mathrm{M} \mathrm{HCl}$ and the inhibition efficiency was more pronounced with increase in the inhibitor concentration.

2) The potentiodynamic polarization curves indicate that derivatives act as mixed type inhibitors.

3) The adsorption of phenylthiourea derivatives on carbon steel surface from $2 \mathrm{M} \mathrm{HCl}$ solution obeys Temkin adsorption isotherm.

4) The inhibition efficiency of phenylthiourea derivatives increases by increasing the inhibitor concentration and decreases with increasing the temperature.

5) Addition of $\mathrm{KI}, \mathrm{KBr}$ and $\mathrm{KSCN}$ to $2 \mathrm{M} \mathrm{HCl}$ solution containing phenylthiourea derivatives enhances the inhibition efficiencies markedly. The combination of inhibitors and these anions shows strong synergistic effects at experimental conditions.

6) The results obtained from polarization and impedance measurements are in good agreement.

\section{REFERENCES}

1. Li, X.; Tang, L. Mater. Chem. Phys. 2005, 90, 286.

2. Singh, D. N.; Dey, A. K. Corrosion 1993, 49, 594.

3. Mu, N. G.; Li, X.; Li, F. Mater. Chem. Phys. 2004, 86, 59.

4. Schmitt, G. Br. Corros. J. 1984, 19, 165.

5. Awad, M. I. J. Appl. Electrochem. 2006, 1163.

6. Rengamani, S.; Muralidharan, S.; AnbuKulandainathan, M.; Iyer, S. V. K. J. Appl. Electrochem. 1994, 24, 355.

7. Amal, M.; Mideen, A. S.; Quraishi, M. A. Corros. Sci. 1994, $36,79$.

8. Fouda, A. S.; Mukhtar, M. M. Chem. Eng. Commun. 2011, 198, 18.

9. Sastri, V. S. Corrosion Inhibitors-Principles and Applications; Wiley: Chichester, England, 1998.

10. Ramesh, P.; Babu, B.; THangavel, K. Anti-Corrosion Methodsand Materials 2005, 52, 219.

11. Fouda, A. S.; Mostafa, H. A.; El-Taib Haekel, Elewady,
G. Y. Corros. Sci. 2005, 47, 1988.

12. Bentiss, F.; Bouanis, M.; Mernari, B.; Traisnel, M.; Vezin, H.; Lagrenee, M. Appl. Surf. Sci. 2005, 252, 950.

13. Bouklah, M.; Benchat, N.; Aouniti, A.; Hammouti, B.; Benkaddour, M.; Lagrenee, M.; Vezin, H.; Bentiss, F. Prog. Org. Coat. 2004, 51, 118.

14. Morales-Gil, P.; Negron-Silva, G.; Romero-Romoa, M.; Angeles-Chavezc, C.; Palomar-Pardave, M. Electrochim. Acta 2004, 49, 4733.

15. Babic-Samardzija, K.; Lupu, C.; Hackerman, N.; Barron, A. R.; Luttge, A. Langmuir 2005, 21, 12187.

16. Bentiss, F.; Traisnel, M.; Gengembre, L.; Lagrenee, M. Appl. Surf. Sci. 1999, 152, 237.

17. Hosseini, M.; Mertens, S. F. L.; GHorbani, M.; Arshadi, M. R. Mater. Chem. Phys. 2003, 78, 800.

18. Behpour, M.; Ghoreishi, S. M.; Soltani, N.; Salavati-Niiasari, M.; Hamadanian, M.; Gandomi, A. Corros. Sci. 2008, 50, 2172.

19. Ashassi-Sorkhabi, H.; Shaabani, B.; Seifzadeh, D. Appl. Surf. Sci. 2005, 239, 154.

20. Bentiss, F.; Traisnel, M.; Lagrenee, M. J. Appl. Electrochem. 2001, 31, 41.

21. Lebrini, M.; Lagrenee, M.; Vezin, H.; Gengembre, L.; Bentiss, F. Corros. Sci. 2005, 47, 485.

22. Bentiss, F.; Lebrini, M.; Vezin; H.; Lagrenee, M. Mater. Chem. Phys. 2004, 87, 18.

23. Abd El-Hamid, A. O.; Abd El-Wahab, B. A. M.; Al-Atom, A. A. Phosphorus, Sulfur and Silicon and the Related Elements 2004, 179, 601.

24. Ogretir, C.; Calis, S.; Bereket, G. J. Mol. Struct. 2003, 635, 229.

25. Bereket, G.; Hur, E.; Ogretir, C. J. Mol. Struct. 2002, 578, 79.

26. Keles, H.; Keles, M.; Dehri, I.; Serindag, O. Mater. Chem. Phys. 2008, 112, 173.

27. Machnikova, E.; Whitmire, K. H.; Hackerman, N. Electrochim. Acta 2008, 53, 6024.

28. Khawar Rauf M.; Badshah, A.; Bolte, M.; Ahmed, I. Acta Cryst. 2007, 63(3), 1155.

29. Abdel Rehim, S. S.; Ibrahim, M. A.; Khaled, K. F. Mater. Chem. Phys. 2001, 70, 268.

30. Dewar, J. S.; Zoebisch, E. G.; Healy, E. H.; Stewart, J. P. J. Am. Chem. Soc. 1985, 107, 3902.

31. Delley, B. J. Chem. Phys. 1990, 92, 508.

32. Delley, B. J. Chem. Phys. 2000, 113, 7756.

33. Mohamed, A.; Mostafa, H. A.; El-Awady, G. Y.; Fouda, A. S. Port Electrchim. Acta 2000, 18, 99.

34. El-Ouafi, A.; Hammouti, B.; Oudda, H.; Kerit, S.; Touzani, R.; Ramdani, A. Anti-Corrosion Methods Materials 2002, 49, 199.

35. Aramaki, K.; Hagiwera, M.; Nishihara, H. Corros. Sci. 1987, 27, 487.

36. Larabi, L.; Harek, Y.; Traisnel, M.; Mansri, A. J Appl. Electrochem. 2004, 34, 833.

37. Trmont, R.; Cabrera, C. R. J. Appl. Electrochem. 2002, 
$32,783$.

38. Fouda, A. S.; AL-Sarawy, A. A.; EL-Katori, E. E. Desalination 2006, 201, 1.

39. Fouda, A. S.; Heakal, F. E.; Radwan, M. S. J. Appl. Electrochem 2009, 39, 391.

40. Elewady, G. Y.; El-Said, I. A.; Fouda, A. S. Int. J. Electrochem. Sci. 2008, 3, 644.

41. El-Ewady, Y. A.; Ahmed, A. I. Indian J. Chem. 1985, 24A, 601.

42. El-Awady, A.; Abd El-Nabey, B.; Aziz, G. Electrochem. Soc. 1992, 139, 2149.

43. Fils, J.; Zakroczymski, T. J. Electrochem. Soc. 1996, 143, 2458.

44. Singh, A. K.; Quraishi, M. A. J. Appl. Electrochem. 2011, $41,7$.

45. Duan, S. Z.; Tao, Y. L. Interface Chem; Higher Education Press: Beijing, 1990; p 124.

46. Abd El-Rehim, S. S.; Refaey, S. A. M.; Taha, F.; Saleh, M. B.; Ahmed, R. A. J. Appl. Electrochem. 2001, 31, 429.

47. Al-Neami, K. K.; Mohamed, A. K.; Kenawy, I. M.;
Fouda, A. S. Monatsh. Chem. 1995, 126, 369.

48. Bentiss, F.; Lebrini, M.; Lagrenee, M. Corros. Sci. 2005, 47, 2915.

49. Abd El-Rehim, S. S.; Ibrahim, M. A. M.; Khaled, K. F. J. Appl. Electrochem. 1999, 29, 593.

50. Fouda, A. S.; Al-Sarawy, A. A.; Radwan, M. S. Ann. Chim. 2006, 96, 85 .

51. Rosliza, R.; Wan Nik W. B.; Senin, H. B.; Mater. Chem. Phys. 2008, 107, 281.

52. Reisde, F. M.; Melo, H. G.; Costa, I. Electrochim. Acta 2006, 51, 1780.

53. Lukovits, I.; Kalman, E.; Bako, I.; Felhosi, I.; Telegdi, J. Proc. $8^{\text {th }}$ European Symposium on Corrosion Inhibitors, Ann. Univ. Ferrara, N.S., Sez V, Suppl. N.10, 1995; p 829.

54. Kalil, N. Electrochim. Acta 2003, 48, 2635.

55. Sastri, V. S.; Corrosion Inhibitors: Principles and applications; Wiley: Chichester, England, 1998.

56. Lagrenee, M.; Mernari, B.; Chaibi, N.; Traisnel, M.; Vezin, H.; Bentiss, F. Corros. Sci. 2001, 43, 951.

57. Mansfeld, F. Eletrochim. Acta 1990, 35, 1533. 